\title{
Effects of exogenous zinc on the photosynthesis and carbonic anhydrase activity of millet (Setaria italica L.)
}

\author{
M.L. CAO*, Y.X. LI*, and H.L. DU*,+ \\ College of Agricultural Science, Shanxi Agricultural University, Taigu, 030801 Shanxi, China* \\ College of Arts and Sciences, Shanxi Agricultural University, Taigu, 030801 Shanxi, China**
}

\begin{abstract}
This study aimed to evaluate the effects of $\mathrm{Zn}$ on the growth safety and activity of carbonic anhydrase (CA) in foxtail millet (Setaria italica L.). The photosynthetic characteristics, CA activity, and relative gene expression of different varieties of millet at the seedling stage were studied by spraying $\mathrm{Zn}$ solution under pot experiment and indoor culture conditions. Results showed that spraying low-concentration $\mathrm{Zn}$ solution $\left(20,40\right.$, and $\left.60 \mathrm{mg} \mathrm{L}^{-1}\right)$ reduced malondialdehyde content and intercellular $\mathrm{CO}_{2}$ concentration $\left(C_{\mathrm{i}}\right)$ but increased antioxidant enzyme activity, pigment content, and photosynthetic gas-exchange parameters (net photosynthetic rate, stomatal conductance, transpiration rate, except for $C_{\mathrm{i}}$ ); meanwhile, spraying high $\mathrm{Zn}$ concentration $\left(80\right.$ and $100 \mathrm{mg} \mathrm{L}^{-1}$ ) exerted opposite effects. The optimal growth of millet was achieved when the $\mathrm{Zn}$ concentration was $40 \mathrm{mg} \mathrm{L}^{-1}$. At this concentration, CA activity increased and $\beta$-CA family expression was upregulated, which exerted little or no effect on other CA families. Compared to Zhangzagu 10 (zinc-resistant variety), Jingu 21 (zinc-sensitive variety) showed a more significant change. This study may serve as a reference for further research on the function of CA and physiological processes, such as photosynthesis in millet, and a theoretical basis for the effective use of $\mathrm{Zn}$ fertilizer in millet.
\end{abstract}

Additional key words: carbonic anhydrase gene family; peroxidase; photosynthetic pigment; superoxide dismutase.

\section{Introduction}

Zinc is an essential trace element for plant growth and development. As the only metal element present in six enzymes, $\mathrm{Zn}$ plays an important regulatory role in plant photosynthesis, protein and nucleic acid metabolism, auxin metabolism, biofilm stability, and cell division (Prasad and Hagemeyer 1999, Kabata-Pendias and Pendias 2001). Appropriate amounts of $\mathrm{Zn}$ can increase the chlorophyll $(\mathrm{Chl})$ content of crops, thereby increasing photosynthetic rate and raising yield (Gartler et al. 2013). High concentrations of $\mathrm{Zn}$ reduce pigment production (Chl, carotenoids, and phycobilisomes), affect PSII activity, and inhibit energy transfer from phycobilisomes to PSII centers, thereby inhibiting the photosynthesis and growth of millet plants (Setaria italica L.) (Zeng et al. 2009, Okmen et al. 2011, Xu et al. 2013). Zinc deficiency leads to the inactivation of certain enzyme cofactors or activators in plants, which negatively affects the physiological processes, such as photosynthesis and stress resistance, of plants (Shrotri et al. 1978, 1979, 1981).
Carbonic anhydrase (CA) is a $\mathrm{Zn}$ metalloenzyme widely found in animals, plants, bacteria, and fungi. Its active center contains $\mathrm{Zn}$, which serves important biological functions, such as catalyzing the reversible hydration reaction between $\mathrm{CO}_{2}$ and $\mathrm{HCO}_{3}^{-}$, converting and diffusing $\mathrm{CO}_{2}$ in respiration, and participating in $\mathrm{pH}$ regulation/adjustment, ion exchange, carboxylation and decarboxylation, and respiration (Khalifah 1971, Atkins et al. 1972, Graham et al. 1984, Moroney et al. 2001). The CA protein family can be divided into six subfamilies, such as $\alpha-, \beta-, \gamma-, \delta-, \varepsilon_{-}$, and $\zeta-\mathrm{CA}$, according to the amino acid sequence homology and crystal structure similarity (Kaul et al. 2001). Higher plants mainly contain three subfamilies, such as $\alpha-, \beta-$, and $\gamma-\mathrm{CA}$, all of which are Zn-containing metalloenzymes. Recent studies have found that CA is closely related to photosynthesis, indicating its great significance in plant growth and development.

Many studies on CA have used rice (Qiao et al. 2014), rape (Deng et al. 2009a), and soybean (Ohki 1978) as test materials to explore the CA catalytic activity and related functions of leaf tissue. However, the $\mathrm{CA}$ activity and

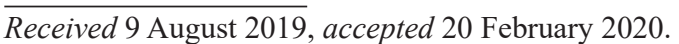

${ }^{+}$Corresponding author; e-mail: duhuiling66@163.com

Abbreviations: CA - carbonic anhydrase; CAT - catalase; cDNA - complementary DNA; $C_{\mathrm{i}}$ - intercellular $\mathrm{CO}_{2}$ concentration; $E$ - transpiration rate; FM - fresh mass; $g_{\mathrm{s}}$ - stomatal conductance; MDA - malondialdehyde; PCR - polymerase chain reaction; $P_{\mathrm{N}}$ - net photosynthetic rate; POD - peroxidase; qPCR - real-time quantitative PCR detecting system; RNA - ribonucleic acid; SOD - superoxide dismutase.

Acknowledgements: The authors thank professor P.Y. Guo for providing the millet seeds. We thank Mr. Y.Y. Wen and his plant physiology laboratory for their help in this experiment. This work was financially supported by the key research and development plan (agricultural field) general project of Shanxi Province (201903D221050). This work was financially supported by the Key Research and Development Project of Shanxi Province (201603D221007-2).
} 
relative expression of millet are poorly understood. This study aims to clarify the relationship among CA, Zn, and photosynthesis, to provide valuable clues for further studies on CA function, and to serve as an important reference for improving the photosynthetic performance and quality of millet.

\section{Materials and methods}

Pot experiment was conducted in the greenhouse of the College of Resources and Environment of Shanxi Agricultural University (May-October 2017). The test soil was collected from Shenfeng Village, Taigu County, Shanxi Province. The soil was calcareous soil with $\mathrm{pH} 8.49$, organic matter content of $19.61 \mathrm{~g} \mathrm{~kg}^{-1}$, alkali nitrogen content of $55.38 \mathrm{mg} \mathrm{kg}^{-1}$, available phosphorus content of $17.54 \mathrm{mg} \mathrm{kg}^{-1}$, available potassium content of 113.85 $\mathrm{mg} \mathrm{kg}^{-1}$, total $\mathrm{N}$ content of $1.180 \mathrm{~g} \mathrm{~kg}^{-1}$, total $\mathrm{P}$ content of $1.261 \mathrm{~g} \mathrm{~kg}^{-1}$, and total $\mathrm{K}$ content of $20.18 \mathrm{~g} \mathrm{~kg}^{-1}$. The millet varieties tested were Zhangzagu 10 (resistant, hybrid) and Jingu 21 (conventional). The $\mathrm{Zn}$ fertilizer tested was $\mathrm{ZnSO}_{4} \cdot 7 \mathrm{H}_{2} \mathrm{O}$.

The pot used in the test pot had an inner diameter of $30 \mathrm{~cm}$ and a height of $25 \mathrm{~cm}$, and was filled in May 2017. Exactly $10 \mathrm{~kg}$ of air-dried soil was filtered on a 6-mm sieve. Part of the soil was placed into the pot and then water was added before sowing. Seeds with full grain and uniform size were sown, and then the remaining soil was evenly covered over the millet until the thickness reached about $3 \mathrm{~cm}$. In consideration of the moisture required for millet growth, water was poured once every $5 \mathrm{~d}$ (tap water). Different concentrations of $\mathrm{Zn}$ solution $(0,20,40$, 60,80 , and $100 \mathrm{mg} \mathrm{L}^{-1}$ ) were sprayed at the seedling stage of millet and recorded as $\mathrm{CK}, \mathrm{Zn} 1, \mathrm{Zn} 2, \mathrm{Zn} 3, \mathrm{Zn} 4$, and Zn5, respectively (35 d after planting). Each treatment was repeated three times. The material was taken on the $7^{\text {th }}$ day after the treatment, and the physiological and photosynthetic indicators were measured.

Laboratory experiment: The experiment was conducted in the laboratory of College of Arts and Sciences, Shanxi Agricultural University (September-November 2017). Two millet varieties of Zhangzagu 10 and Jingu 21 were selected. Plump and well-sized seeds were selected, disinfected with $0.1 \% \mathrm{HgCl}_{2}$, and washed repeatedly with distilled water. The water on the seeds was absorbed by filter paper, dried in the shade, and then sown in a Petri dish with a diameter of $90 \mathrm{~mm}$ with 100 capsules per dish. The seeding substrate was distilled water, with $5 \mathrm{~mL}$ per dish, and the culture dish was placed in a ZZSW-ZPO2II-type light culture rack (Shanghai Zhizhong Laboratory Equipment, Ltd.). The culture temperature was $25-28^{\circ} \mathrm{C}$, the illumination was $12 \mathrm{~h}$ per day, and light intensity was 72-126 $\mu \mathrm{mol}$ (photon) $\mathrm{m}^{-2} \mathrm{~s}^{-1}$. After germination, the seeds were watered three times a day, with $3 \mathrm{~mL}$ each time. After the plants were sown for $30 \mathrm{~d}$, leaves were treated. The $\mathrm{Zn}$ solution was sprayed at the seedling stage at concentrations of 0 and $40 \mathrm{mg} \mathrm{L}^{-1}$, which were recorded as CK and Zn2, respectively. Each treatment was repeated three times. On the $7^{\text {th }}$ day after the treatment, the CA activity and the relative gene expression were measured.

Antioxidant enzyme activity and malondialdehyde (MDA) content: Superoxide dismutase (SOD, EC 1.15.1.1) activity was determined by the nitroblue tetrazolium photochemical reduction inhibition method (Gao 2006), peroxidase (POD, EC 1.11.1.7) activity by the guaiacol method (Gao 2006), catalase (CAT, EC 1.11.1.6) activity by ultraviolet spectrophotometry (Gao 2006), and malondialdehyde (MDA) content by thiobarbituric acid spectrophotometry (Gao 2006). The pigment contents of the leaves were determined using acetone extraction (Gao 2006). Ultraviolet-visible spectrophotometer ( $U V-5100 H$, Shanghai Yuanxi Laboratory Equipment Co., Ltd., China) was used in the test. The activities were presented as the number of units per gram of fresh mass.

Photosynthetic characteristics: Net photosynthetic rate $\left(P_{\mathrm{N}}\right)$, transpiration rate $(E)$, intercellular $\mathrm{CO}_{2}$ concentration $\left(C_{\mathrm{i}}\right)$, and stomatal conductance $\left(g_{\mathrm{s}}\right)$ were measured using a CI-340 handheld photosynthesis measurement system (CID Bio-Science, Inc., USA). Three samples of millet seedlings were randomly selected from 9:00-11:00 h on the $7^{\text {th }}$ day after spraying the $\mathrm{Zn}$ solution, and the gasexchange parameters were determined. The measurement was carried out with a fixed red-blue light source; the light intensity was $900 \pm 50 \mu \mathrm{mol}$ (photon) $\mathrm{m}^{-2} \mathrm{~s}^{-1}$, the air temperature was $23 \pm 2{ }^{\circ} \mathrm{C}$, and the $\mathrm{CO}_{2}$ concentration was $400 \pm 50 \mu \mathrm{mol} \mathrm{mol}^{-1}$.

CA (EC 4.2.1.1) activity: The test was carried out using the plant CA enzyme-linked immunosorbent assay kit of Shanghai Bio-Jining Industrial Co., Ltd. (China). The activity was presented as the number of units per gram of fresh mass.

\section{Gene expression}

Total RNA extraction: Fresh leaves (35 mg) were weighed from each sample and extracted using the total RNA extraction kit of Tiangen Biotechnology Co., Ltd. (China). The purity and integrity of the RNA were determined by micro-spectrophotometry (UV-8000, Shanghai Yuanxi Laboratory Equipment Co., Ltd., China) and agarose gel electrophoresis (JY-SPCT, Beijing Junyi Laboratory Equipment Co., Ltd., China), respectively, after extraction.

Reverse transcription: Total RNA $(5 \mu \mathrm{L})$ was used as a reverse transcription template. Reverse transcription was performed by QuantScript RT of Tiangen Biotechnology Co., Ltd., and first-strand cDNA was synthesized by oligodT, a reverse transcription primer. The reverse transcription system $(20 \mu \mathrm{L})$ was as follows:

\begin{tabular}{ll}
\hline Composition & Dosage $[\mu \mathrm{L}]$ \\
\hline Total RNA & 5.0 \\
OligodT primer $(10 \mu \mathrm{M})$ & 1.0 \\
$5 \times$ RT MasterMix & 4.0 \\
RNase-free $\mathrm{H}_{2} \mathrm{O}$ to final volume & 20.0 \\
\hline
\end{tabular}


Primer design: The primers required for the essay were designed according to the special requirements of the primer design by real-time quantitative PCR. The primer sequences are shown in the text table, actin is the reference gene in millet. the antioxidant enzyme activities of the two varieties initially increased and then decreased, and these changes were different between varieties (Fig. 1). The antioxidant enzyme activities reached the highest levels after $\mathrm{Zn} 2$ treatment in each variety and were significantly different

\begin{tabular}{llll}
\hline Gene family & Primer & Sequences [5' $\rightarrow$ ''] & NCBI retrieval \\
\hline$\alpha$-CA & SiCA1-F & CGCAATGCGCGAGAGGGACG & XM-004975507 \\
& SiCA1-R & GCGTACAGCGCGGCCAGCTT & \\
& SiCA2-F & GCCGCACTATTGTATGTTTGC & XM-004954909 \\
& SiCA2-R & CTCCGAGTATAATTCAGCCAG & \\
& SiCA3-F & CGCCACTGTCGGGGCGCTC & XM-004973687 \\
& SiCA3-R & CGCTCGATGGCGGGCTGCAG & \\
& SiCA4-F & GTACGCGGCGGCGGCCCTGG & XM-004965848 \\
& SiCA4-R & CCAGCCTGCGTATGGTCCGA & \\
& SiCA5-F & GCATATGGGTCGTCCAGCTC & XM-004973604 \\
& SiCA5-R & GTAGAGGACGCCGATCACCGC & \\
& SiCA6-F & CGAGGTCCTTGGGATCAGCGG & XM-012844113 \\
& SiCA6-R & CAGCAAACTCTAGTGCAGCAC & \\
& SiCA7-F & GCAACTACTTCTTCCACGAG & XM-004967603 \\
& SiCA7-R & CTATTTCATCATCAGTGAGC & \\
& SiCA8-F & CTCGGATCCACCCTCCAGG & XM-004958441 \\
& SiCA8-R & TGTGCGCATACTTCTTCCTC & \\
& Siactin-F & TGTGACAATGGTACTGGAATG & XM-004970638 \\
& Siactin-R & CAAGGTCCAATCGAAGAATAG & \\
\hline
\end{tabular}

Real-time PCR: The SYBR Green-qPCR method was used for amplification using a QuantStudio 6 real-time quantitative PCR instrument (MA-1620Q, Shandong Boke Laboratory Equipment Co., Ltd., China). The amplification conditions were as follows: predenaturation at $95^{\circ} \mathrm{C}$ for $2 \mathrm{~min}$; denaturation at $95^{\circ} \mathrm{C}$ for $10 \mathrm{~s}$; annealing at $60^{\circ} \mathrm{C}$ for $30 \mathrm{~s}$; extension at $72^{\circ} \mathrm{C}$ for $1 \mathrm{~min}, 40$ cycles. The reaction system was as follows:

\begin{tabular}{ll}
\hline Composition & Dosage $[\mu \mathrm{L}]$ \\
\hline Primer F $[10 \mu \mathrm{M}]$ & 1 \\
Primer R $[10 \mu \mathrm{M}]$ & 1 \\
$5 \times$ Pfu buffer & 5 \\
dNTPs $[2.5 \mathrm{Mm}]$ & 2 \\
Pfu polymerase $\left[2.5 \mathrm{U} \cdot \mu \mathrm{L}^{-1}\right]$ & 0.5 \\
cDNA template & 2 \\
SYBR Green I & 5 \\
ddH $\mathrm{H}_{2} \mathrm{O}$ to final volume & 25 \\
\hline
\end{tabular}

Statistical analysis: The data were plotted using Microsoft Excel software, analyzed by analysis of variance (ANOVA) with SPSS 17.0, and tested by Duncan's new complex range method for significance. Gene expression was calculated using the $2^{-\Delta \Delta \mathrm{CT}}$ method.

\section{Results}

Antioxidant enzyme activity: After spraying Zn on millet, from those under CK. However, the antioxidant enzyme activities under $\mathrm{Zn} 4$ were lower than those under CK, and the effect of $\mathrm{Zn} 5$ treatment was more obvious. Compared with $\mathrm{CK}, \mathrm{Zn} 1, \mathrm{Zn} 2$, and $\mathrm{Zn} 3$ treatment increased the SOD activity of Jingu 21 by $12.0,19.6$, and $8.9 \%$, respectively, while those of Zhangzagu 10 by $2.6,7.8$, and $3.0 \%$, respectively. Compared with $\mathrm{CK}, \mathrm{Zn} 4$ and Zn5 treatment decreased the SOD activity of Jingu 21 by 2.9 and $7.1 \%$, respectively, and those of Zhangzagu 10 by 2.5 and $5.3 \%$, respectively. Compared with $\mathrm{CK}, \mathrm{Zn} 1, \mathrm{Zn} 2$, and $\mathrm{Zn} 3$ treatment increased the POD activity of Jingu 21 by 12.7 , 26.1 , and $7.3 \%$, respectively, while those of Zhangzagu 10 by $6.1,10.4$, and $4.4 \%$, respectively. Compared with $\mathrm{CK}, \mathrm{Zn} 4$ and Zn5 treatment decreased the POD activity of Jingu 21 by 8.6 and $17.0 \%$, respectively, and those of Zhangzagu 10 by 1.7 and $7.6 \%$, respectively. Compared with $\mathrm{CK}, \mathrm{Zn} 1, \mathrm{Zn} 2$ and $\mathrm{Zn} 3$ treatment increased the CAT activity of Jingu 21 by $12.6,24.3$, and $9.5 \%$, respectively, while those of Zhangzagu 10 by $2.1,4.2$, and $1.7 \%$, respectively. Compared with CK, Zn4 and Zn5 treatment decreased the CAT activity of Jingu 21 by 8.0 and $10.8 \%$, respectively, and those of Zhangzagu 10 by 2.1 and $4.4 \%$, respectively. The change degree of Jingu 21 was higher than that of Zhangzagu 10, and POD activity changed the most among the three antioxidant enzymes.

Malondialdehyde content: The trend of MDA content was opposite that of the antioxidant enzymes. As shown in Fig. $1 D$, the MDA content initially decreased and then increased with the increasing $\mathrm{Zn}$ concentration. The MDA 


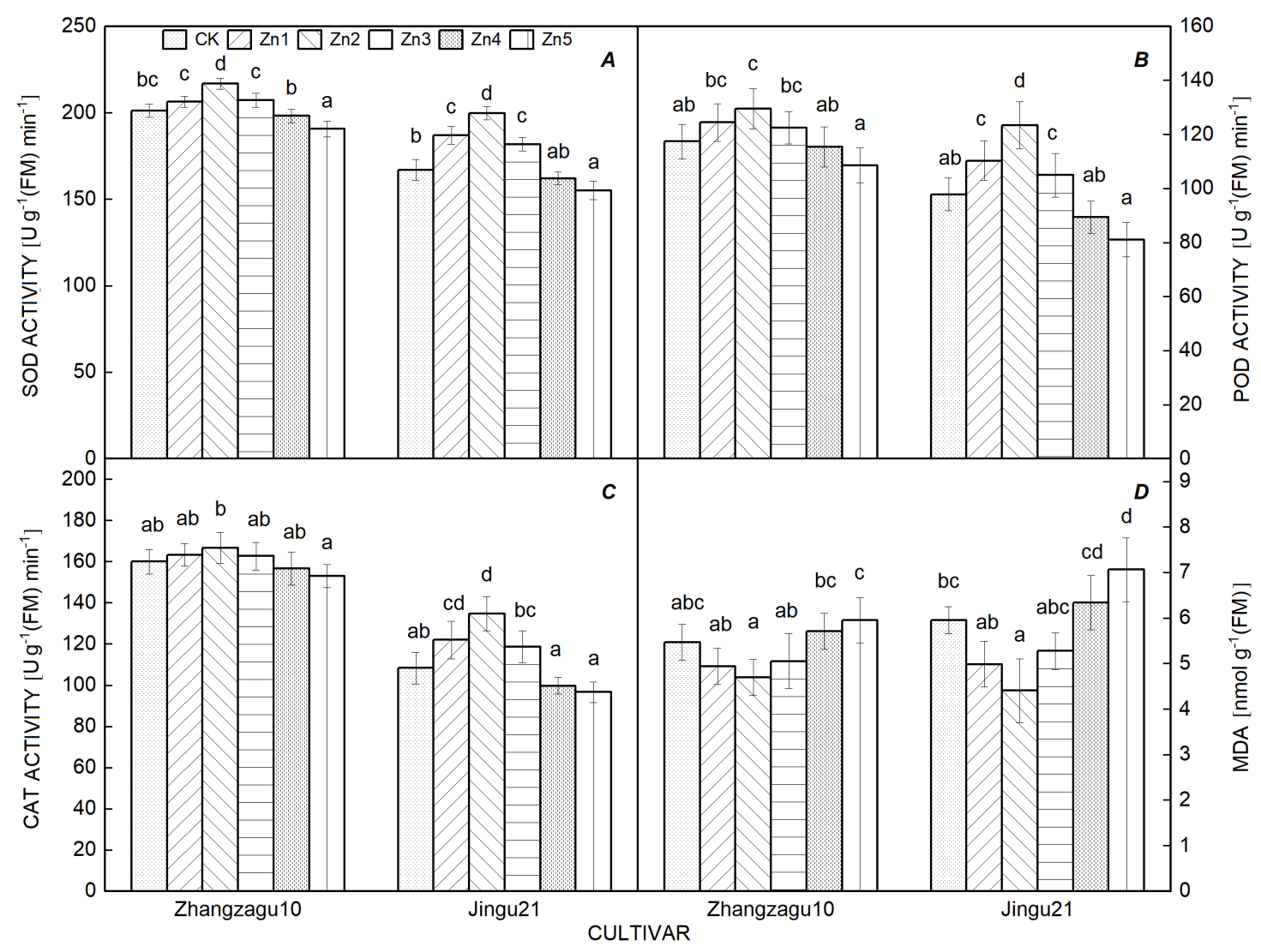

Fig. 1. Effects of different exogenous zinc concentrations on the superoxide dismutase (SOD) $(A)$, peroxidase (POD) $(B)$, catalase (CAT) $(C)$ activities, and malondialdehyde content $(D)$ of two millet varieties. The leaves of two millet cultivars were determined at the seedling stage. Different letters per treatment indicate statistical significant differences $(p<0.05)$ showed by Tukey's test. Different concentrations of $\mathrm{Zn}$ solution $\left(0,20,40,60,80\right.$, and $\left.100 \mathrm{mg} \mathrm{L}^{-1}\right)$ were sprayed at the seedling stage of millet and recorded as $\mathrm{CK}, \mathrm{Zn} 1, \mathrm{Zn} 2, \mathrm{Zn} 3, \mathrm{Zn} 4$, and $\mathrm{Zn} 5$, respectively.

content reached a minimum value and then gradually increased under $\mathrm{Zn} 2$, and it was higher under $\mathrm{Zn} 4$ than that in CK. Compared with CK, Zn1, Zn2, and Zn3 treatment for $7 \mathrm{~d}$ decreased the MDA contents of Jingu 21 by 16.3 , 26.0 , and $11.4 \%$, respectively, while those of Zhangzagu 10 by $9.7,14.2$, and $7.6 \%$, respectively. Compared with $\mathrm{CK}, \mathrm{Zn} 4$ and $\mathrm{Zn} 5$ treatment for $7 \mathrm{~d}$ increased the MDA contents of Jingu 21 by 6.5 and $18.7 \%$, respectively, and those of Zhangzagu 10 by 4.4 and $8.8 \%$, respectively.

Pigment content: The effect of $\mathrm{Zn}$ on the pigment content of millet leaves is shown in Table 1. The pigment content in the leaves of millet increased with the increasing $\mathrm{Zn}$ concentration until $\mathrm{Zn} 2$. However, the pigment content under both $\mathrm{Zn} 4$ and $\mathrm{Zn} 5$ treatments decreased, and the content was even lower than that under CK. Although the two varieties showed similar trends, they differed in the degree of increase or decrease in their pigment content, and the change degree in Jingu 21 was significantly higher than that in Zhangzagu 10.

Compared with CK, Zn1 treatment for $7 \mathrm{~d}$ significantly increased the $\mathrm{Chl} a, \mathrm{Chl} b$, total $\mathrm{Chl}$, and carotenoid contents of Jingu 21 by $9.0,9.3,9.0$, and $5.5 \%$, respectively, and those of Zhangzagu 10 by $4.9,8.1,5.8$, and $4.9 \%$, respectively. $\mathrm{Zn} 2$ treatment for $7 \mathrm{~d}$ significantly increased the $\mathrm{Chl} a$, Chl $b$, total $\mathrm{Chl}$, and carotenoid contents of Jingu 21 by $13.7,24.0,16.2$, and $7.9 \%$, respectively, and those of Zhangzagu 10 by $7.6,11.9,8.8$, and $5.3 \%$, respectively. $\mathrm{Zn} 3$ treatment for $7 \mathrm{~d}$ significantly increased Chl $a$, Chl $b$, total Chl, and carotenoid contents of Jingu 21 by $6.8,7.3,6.9$, and $2.4 \%$, respectively, and those of Zhangzagu 10 by $3.4,5.5,4.0$, and $1.9 \%$, respectively. Compared with CK, Zn 4 treatment for $7 \mathrm{~d}$ decreased Chl $a$, Chl $b$, total Chl, and carotenoid contents of Jingu 21 by $4.5,9.1,5.7$, and $3.5 \%$, respectively, and those of Zhangzagu 10 by 3.2, 7.9, 4.5, and $2.3 \%$, respectively. Zn5 treatment for $7 \mathrm{~d}$ decreased Chl $a$, Chl $b$, total Chl, and carotenoid contents of Jingu 21 by 9.5, 18.2, 11.6, and $4.1 \%$, respectively, and those of Zhangzagu 10 by 5.4 , $13.3,7.6$, and $3.4 \%$, respectively, which reached significant levels except for carotenoids. Chl $b$ content changed the most among the four pigment indicators.

Photosynthetic gas-exchange parameters: After $\mathrm{Zn}$ treatment, the $P_{\mathrm{N}}, g_{\mathrm{s}}$, and $E$ of the two varieties initially increased and then decreased with increasing $\mathrm{Zn}$ concentration. Changes in these indicators differed between varieties (Table 2). The three indicators reached their 
maximum levels in $\mathrm{Zn} 2$ and then gradually decreased. These indicators were lower under Zn4 than under CK and reached a significant level between treatments. Compared with $\mathrm{CK}, \mathrm{Zn} 2$ treatment for $7 \mathrm{~d}$ significantly increased the $P_{\mathrm{N}}, g_{\mathrm{s}}$, and $E$ of Jingu 21 by $11.4,5.3$, and $6.0 \%$, respectively, and those of Zhangzagu 10 by $7.7,3.6$, and $4.2 \%$, respectively. $\mathrm{Zn} 2$ treatment for $7 \mathrm{~d}$ significantly increased the $P_{\mathrm{N}}, g_{\mathrm{s}}$, and $E$ of Jingu 21 by $22.2,8.8$, and $9.8 \%$, respectively, and those of Zhangzagu 10 by $16.0,6.0$, and $7.0 \%$, respectively. Zn3 treatment for $7 \mathrm{~d}$ significantly increased the $P_{\mathrm{N}}, g_{\mathrm{s}}$, and $E$ of Jingu 21 by $8.1,4.0$, and $5.1 \%$, respectively, and those of Zhangzagu 10 by $6.1,2.7$, and $3.1 \%$, respectively. Compared with $\mathrm{CK}, \mathrm{Zn} 4$ treatment for $7 \mathrm{~d}$ decreased the $P_{\mathrm{N}}, g_{\mathrm{s}}$, and $E$ of Jingu 21 by $11.2,5.0$, and $5.4 \%$, respectively, and those of Zhangzagu 10 by $6.4,2.2$, and $3.1 \%$, respectively. Zn5 treatment for $7 \mathrm{~d}$ decreased the $P_{\mathrm{N}}, g_{\mathrm{s}}$, and $E$ of Jingu 21 by $16.1,8.5$, and $10.1 \%$, respectively, and those of Zhang- zagu 10 by $12.9,4.7$, and $6.0 \%$, respectively (Table 2 ). $P_{\mathrm{N}}$ changed the most among the three indicators and the change degree in Jingu 21 was significantly higher than that in Zhangzagu 10.

As the concentration of $\mathrm{Zn}$ increased, $C_{\mathrm{i}}$ initially decreased and then increased, which was in contrary to the trend of $P_{\mathrm{N}}$, and the reduction was the most obvious under $\mathrm{Zn} 2$ treatment (Table 2). Compared with $\mathrm{CK}, \mathrm{Zn} 1, \mathrm{Zn} 2$ and $\mathrm{Zn} 3$ treatment for $7 \mathrm{~d}$ significantly decreased the $C_{\mathrm{i}}$ of Jingu 21 by $11.3,16.9$, and $6.2 \%$, respectively, while those of Zhangzagu 10 by $8.0,11.2$, and $4.0 \%$, respectively. Compared with $\mathrm{CK}, \mathrm{Zn} 4$ and Zn5 treatment for $7 \mathrm{~d}$ increased the $C_{\mathrm{i}}$ of Jingu 21 by 4.5 and $7.2 \%$, respectively, and those of Zhangzagu 10 by 2.4 and $5.4 \%$, respectively. The change trend of $C_{\mathrm{i}}$ in Jingu 21 in the different $\mathrm{Zn}$ concentrations was as follows: $\mathrm{Zn} 5>\mathrm{Zn} 4>\mathrm{CK}>\mathrm{Zn} 3>$ $\mathrm{Zn} 2>\mathrm{Zn} 1$. Zhangzagu 10 exhibited a similar trend. Although Zhangzagu 10 and Jingu 21 showed similar

Table 1. Effect of exogenous zinc on the pigment content of millet leaves. Values are means $\pm \operatorname{SE}(n=3)$. Different letters in the same column indicate significant difference at the $p<0.05$ level by Duncan's new multiple range test. Different concentrations of $\mathrm{Zn}$ solution $\left(0,20,40,60,80\right.$, and $\left.100 \mathrm{mg} \mathrm{L}^{-1}\right)$ were sprayed at the seedling stage of millet and recorded as $\mathrm{CK}, \mathrm{Zn} 1, \mathrm{Zn} 2, \mathrm{Zn} 3, \mathrm{Zn} 4$, and Zn5, respectively.

\begin{tabular}{llclll}
\hline Cultivar & Treatment & Chl $a\left[\mathrm{mg} \mathrm{g}^{-1}(\mathrm{FM})\right]$ & $\mathrm{Chl} b\left[\mathrm{mg} \mathrm{g}^{-1}(\mathrm{FM})\right]$ & $\mathrm{Chl}(a+b)\left[\mathrm{mg} \mathrm{g}^{-1}(\mathrm{FM})\right]$ & Carotenoid $\left[\mathrm{mg} \mathrm{g}^{-1}(\mathrm{FM})\right]^{\circ}$ \\
\hline Zhangzagu 10 & CK & $9.66 \pm 0.18^{\mathrm{c}}$ & $3.77 \pm 0.17^{\mathrm{b}}$ & $13.43 \pm 0.11^{\mathrm{c}}$ & $1.40 \pm 0.04^{\mathrm{ab}}$ \\
& Zn1 & $10.13 \pm 0.05^{\mathrm{d}}$ & $4.07 \pm 0.12^{\mathrm{cd}}$ & $14.21 \pm 0.17^{\mathrm{e}}$ & $1.47 \pm 0.04^{\mathrm{c}}$ \\
& Zn2 & $10.40 \pm 0.09^{\mathrm{e}}$ & $4.21 \pm 0.03^{\mathrm{d}}$ & $14.62 \pm 0.10^{\mathrm{f}}$ & $1.47 \pm 0.03^{\mathrm{c}}$ \\
& Zn3 & $9.99 \pm 0.07^{\mathrm{d}}$ & $3.97 \pm 0.11^{\mathrm{c}}$ & $13.96 \pm 0.04^{\mathrm{d}}$ & $1.42 \pm 0.01^{\mathrm{bc}}$ \\
& Zn4 & $9.35 \pm 0.10^{\mathrm{b}}$ & $3.47 \pm 0.09^{\mathrm{a}}$ & $12.82 \pm 0.19^{\mathrm{b}}$ & $1.36 \pm 0.05^{\mathrm{ab}}$ \\
& Zn5 & $9.14 \pm 0.10^{\mathrm{a}}$ & $3.27 \pm 0.11^{\mathrm{a}}$ & $12.41 \pm 0.10^{\mathrm{a}}$ & $1.35 \pm 0.02^{\mathrm{a}}$ \\
Jingu 21 & CK & $7.36 \pm 0.11^{\mathrm{c}}$ & $2.38 \pm 0.16^{\mathrm{bc}}$ & $9.74 \pm 0.16^{\mathrm{c}}$ & $1.31 \pm 0.09^{\mathrm{ab}}$ \\
& Zn1 & $8.02 \pm 0.12^{\mathrm{d}}$ & $2.60 \pm 0.32^{\mathrm{c}}$ & $10.62 \pm 0.25^{\mathrm{d}}$ & $1.38 \pm 0.13^{\mathrm{ab}}$ \\
& Zn2 & $8.36 \pm 0.09^{\mathrm{e}}$ & $2.95 \pm 0.13^{\mathrm{d}}$ & $11.32 \pm 0.12^{\mathrm{e}}$ & $1.42 \pm 0.03^{\mathrm{b}}$ \\
& Zn3 & $7.86 \pm 0.05^{\mathrm{d}}$ & $2.56 \pm 0.14^{\mathrm{c}}$ & $10.41 \pm 0.19^{\mathrm{d}}$ & $1.34 \pm 0.05^{\mathrm{ab}}$ \\
& Zn4 & $7.02 \pm 0.09^{\mathrm{b}}$ & $2.17 \pm 0.07^{\mathrm{ab}}$ & $9.19 \pm 0.16^{\mathrm{b}}$ & $1.27 \pm 0.01^{\mathrm{a}}$ \\
& Zn5 & $6.66 \pm 0.09^{\mathrm{a}}$ & $1.95 \pm 0.17^{\mathrm{a}}$ & $8.61 \pm 0.09^{\mathrm{a}}$ & $1.26 \pm 0.08^{\mathrm{a}}$ \\
\hline
\end{tabular}

Table 2. Effect of exogenous zinc on photosynthetic gas-exchange parameters of millet. Values are means $\pm \mathrm{SE}(n=3)$. Different letters in the same column indicate significant difference at the $p<0.05$ level by Duncan's new multiple range test. Different concentrations of $\mathrm{Zn}$ solution $\left(0,20,40,60,80\right.$, and $\left.100 \mathrm{mg} \mathrm{L}^{-1}\right)$ were sprayed at the seedling stage of millet and recorded as $\mathrm{CK}, \mathrm{Zn} 1, \mathrm{Zn} 2, \mathrm{Zn} 3, \mathrm{Zn} 4$, and $\mathrm{Zn} 5$, respectively. $P_{\mathrm{N}}-$ net photosynthetic rate; $g_{\mathrm{s}}$ - stomatal conductance; $E$ - transpiration rate; $C_{\mathrm{i}}-$ intercellular $\mathrm{CO}_{2}$ concentration.

\begin{tabular}{llllll}
\hline Cultivar & Treatment & $P_{\mathrm{N}}\left[\mu \mathrm{mol} \mathrm{m}{ }^{-2} \mathrm{~s}^{-1}\right]$ & $g_{\mathrm{s}}\left[\mathrm{mmol} \mathrm{m}^{-2} \mathrm{~s}^{-1}\right]$ & $E\left[\mathrm{mmol} \mathrm{m}^{-2} \mathrm{~s}^{-1}\right]$ & $C_{\mathrm{i}}\left[\mu \mathrm{mol} \mathrm{mol}^{-1}\right]$ \\
\hline Zhangzagu 10 & CK & $6.95 \pm 0.13^{\mathrm{c}}$ & $54.92 \pm 0.56^{\mathrm{c}}$ & $2.388 \pm 0.051^{\mathrm{c}}$ & $212.05 \pm 1.05^{\mathrm{d}}$ \\
& Zn1 & $7.50 \pm 0.21^{\mathrm{d}}$ & $56.90 \pm 0.34^{\mathrm{e}}$ & $2.489 \pm 0.019^{\mathrm{e}}$ & $195.18 \pm 1.28^{\mathrm{b}}$ \\
& Zn2 & $8.07 \pm 0.15^{\mathrm{e}}$ & $58.24 \pm 0.27^{\mathrm{f}}$ & $2.555 \pm 0.020^{\mathrm{f}}$ & $188.22 \pm 2.54^{\mathrm{a}}$ \\
& Zn3 & $7.38 \pm 0.11^{\mathrm{d}}$ & $56.42 \pm 0.44^{\mathrm{d}}$ & $2.463 \pm 0.023^{\mathrm{d}}$ & $203.63 \pm 4.39^{\mathrm{c}}$ \\
& Zn4 & $6.51 \pm 0.13^{\mathrm{b}}$ & $53.71 \pm 0.29^{\mathrm{b}}$ & $2.314 \pm 0.016^{\mathrm{b}}$ & $217.23 \pm 3.26^{\mathrm{e}}$ \\
& Zn5 & $6.06 \pm 0.22^{\mathrm{a}}$ & $52.35 \pm 0.27^{\mathrm{a}}$ & $2.243 \pm 0.014^{\mathrm{a}}$ & $223.44 \pm 2.49^{\mathrm{f}}$ \\
Jingu 21 & CK & $5.76 \pm 0.13^{\mathrm{c}}$ & $50.56 \pm 0.84^{\mathrm{c}}$ & $2.154 \pm 0.071^{\mathrm{c}}$ & $249.58 \pm 1.33^{\mathrm{d}}$ \\
& Zn1 & $6.42 \pm 0.12^{\mathrm{e}}$ & $53.23 \pm 0.39^{\mathrm{e}}$ & $2.284 \pm 0.029^{\mathrm{d}}$ & $221.47 \pm 0.82^{\mathrm{b}}$ \\
& Zn2 & $7.04 \pm 0.13^{\mathrm{f}}$ & $55.02 \pm 0.20^{\mathrm{f}}$ & $2.365 \pm 0.011^{\mathrm{e}}$ & $207.34 \pm 1.73^{\mathrm{a}}$ \\
& Zn3 & $6.23 \pm 0.14^{\mathrm{d}}$ & $52.61 \pm 0.34^{\mathrm{d}}$ & $2.265 \pm 0.013^{\mathrm{d}}$ & $234.20 \pm 4.38^{\mathrm{c}}$ \\
& Zn4 & $5.11 \pm 0.15^{\mathrm{b}}$ & $48.05 \pm 0.12^{\mathrm{b}}$ & $2.037 \pm 0.021^{\mathrm{b}}$ & $260.70 \pm 3.12^{\mathrm{e}}$ \\
& Zn5 & $4.83 \pm 0.18^{\mathrm{a}}$ & $46.24 \pm 0.33^{\mathrm{a}}$ & $1.937 \pm 0.036^{\mathrm{a}}$ & $267.47 \pm 2.31^{\mathrm{f}}$ \\
\hline
\end{tabular}


trends at different concentrations, the increase or decrease in $C_{\mathrm{i}}$ was not the same, and the change in Jingu 21 was significantly higher than that in Zhangzagu 10.

CA activity and relative gene expression: CA activity increased after $\mathrm{Zn} 2$ treatment, the CA activities of Jingu 21 and Zhangzagu 10 increased by 45.2 and $26.6 \%$, respectively (Fig. 2). Compared to Zhangzagu 10, Jingu 21 showed a greater change, but both reached significant levels.

Table 3 shows that after Zn treatment, SiCA1, SiCA2,

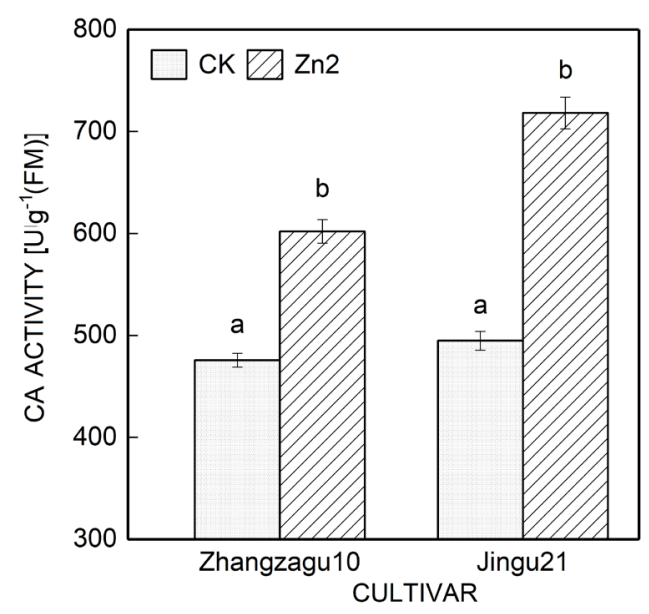

Fig. 2. Effect of exogenous zinc on carbonic anhydrase (CA) activity of millet leaves. Leaves of two millet cultivars were determined at the seedling stage. Different letters per treatment indicate statistical significant differences $(p<0.05)$ showed by Tukey's test. The Zn solution was sprayed at the seedling stage at concentrations of 0 and $40 \mathrm{mg} \mathrm{L}^{-1}$, which were recorded as CK and $\mathrm{Zn} 2$, respectively. and $\mathrm{SiCA7}$ genes from the CA gene family were not expressed in the two varieties, and the expression levels of $\mathrm{SiCA3}, \mathrm{SiCA4}, \mathrm{SiCA5}$, and $\mathrm{SiCA} 8$ were lower. However, the degree of change of Jingu 21 was greater than that of Zhangzagu 10. A higher expression level was obtained only in SiCA6, indicating that $\mathrm{Zn}$ induces the expression of the $\beta$-CA family but exerts little or no effect on the $\alpha$ and $\gamma$ families. Compared with $\mathrm{CK}, \mathrm{Zn} 2$ treatment for $7 \mathrm{~d}$ significantly increased the relative expression of the $\mathrm{SiCA6}$ gene of Jingu 21 and Zhangzagu 10 by 160.7 and $253.9 \%$, respectively.

\section{Discussion}

Zinc is an essential trace element in plant metabolism (Rengel 1999, Kabata-Pendias and Pendias 2001) and moderate amounts of $\mathrm{Zn}$ can promote plant growth. However, excessive amounts can cause plant toxicity (Chaney 1993), which also exerts a specific impact on the Calvin cycle and optical system activities (Van Assche and Clijsters 1986). Zinc can activate several antioxidant enzymes, such as SOD, POD, and CAT (Jat et al. 2007, Saeed et al. 2013). Fernàndez-Martínez et al. (2014) showed that plant photoprotection and antioxidant capacity increase with increasing $\mathrm{Zn}$ concentration; however, high concentrations of $\mathrm{Zn}$ produce high toxicity, which can reduce crop biomass, decrease photosynthetic pigment content, and damage the photochemical processes and photosynthesis. Mateos-Naranjo et al. (2014) showed that a suitable amount of $\mathrm{Zn}\left(30 \mathrm{mmol} \mathrm{L}^{-1}\right)$ can increase the total biomass, relative growth rate, and photosynthetic pigment content of Juncus acutus, but high concentrations of $\mathrm{Zn}$ (> $60 \mathrm{mmol} \mathrm{L}^{-1}$ ) inhibit plant growth, reduce its growth rate and photosynthetic pigment content, and affect the chlorophyll fluorescence characteristics. This study shows

Table 3. Effect of exogenous zinc on the relative expression of carbonic anhydrase (CA) genes. The Zn solution was sprayed at the seedling stage at concentrations of 0 and $40 \mathrm{mg} \mathrm{L}^{1}$, which were recorded as $\mathrm{CK}$ and $\mathrm{Zn} 2$, respectively.

\begin{tabular}{|c|c|c|c|c|}
\hline Cultivar & Gene family & Gene name & $\begin{array}{l}\text { Treatment } \\
\text { CK }\end{array}$ & $\mathrm{Zn} 2$ \\
\hline \multirow[t]{8}{*}{ Zhangzagu 10} & \multirow[t]{5}{*}{$\alpha-\mathrm{CA}$} & SiCA1 & $0.0010 \pm 0.0001$ & $0.0036 \pm 0.0002$ \\
\hline & & SiCA2 & $0.0012 \pm 0.0001$ & $0.0043 \pm 0.0002$ \\
\hline & & $S i C A 3$ & $0.2436 \pm 0.0180$ & $0.3645 \pm 0.0118$ \\
\hline & & $\mathrm{SiCA4}$ & $0.1882 \pm 0.0013$ & $0.2194 \pm 0.0137$ \\
\hline & & SiCA5 & $0.2362 \pm 0.0142$ & $0.3585 \pm 0.0097$ \\
\hline & $\beta-\mathrm{CA}$ & SiCA6 & $0.8222 \pm 0.0370$ & $2.1437 \pm 0.0258$ \\
\hline & \multirow[t]{2}{*}{$\gamma-\mathrm{CA}$} & SiCA7 & $0.0013 \pm 0.0001$ & $0.0156 \pm 0.0008$ \\
\hline & & SiCA8 & $0.2719 \pm 0.0124$ & $0.3718 \pm 0.0273$ \\
\hline \multirow[t]{8}{*}{ Jingu 21} & \multirow[t]{5}{*}{$\alpha-\mathrm{CA}$} & SiCA1 & $0.0630 \pm 0.0065$ & $0.2386 \pm 0.0338$ \\
\hline & & $\mathrm{SiCA} 2$ & $0.0641 \pm 0.0003$ & $0.2579 \pm 0.0153$ \\
\hline & & $S i C A 3$ & $0.2521 \pm 0.0153$ & $0.5312 \pm 0.0202$ \\
\hline & & SiCA4 & $0.2763 \pm 0.0115$ & $0.6215 \pm 0.0202$ \\
\hline & & SiCA5 & $0.2711 \pm 0.0029$ & $0.6043 \pm 0.0064$ \\
\hline & $\beta-\mathrm{CA}$ & SiCA6 & $0.9463 \pm 0.0235$ & $3.3486 \pm 0.0750$ \\
\hline & \multirow[t]{2}{*}{$\gamma-\mathrm{CA}$} & SiCA7 & $0.0698 \pm 0.0093$ & $0.2854 \pm 0.0122$ \\
\hline & & SiCA8 & $0.3511 \pm 0.0049$ & $0.9182 \pm 0.0195$ \\
\hline
\end{tabular}


that low concentrations of $\mathrm{Zn}\left(20,40\right.$, and $\left.60 \mathrm{mg} \mathrm{L}^{-1}\right)$ can activate the production of antioxidant enzymes, reduce the content of harmful substances of MDA, and promote photosynthesis, but the high concentrations of $\mathrm{Zn}$ (80 and $100 \mathrm{mg} \mathrm{L}^{-1}$ ) can inhibit the production of protective enzymes, increase MDA content, and affect photosynthesis, thus influencing crop growth. The results are consistent with those reported above. Zinc plays an important role in the anti-lipid peroxidation of millet. The suitable $\mathrm{Zn}$ concentration can alleviate the peroxidation of membrane lipids and improve the antioxidant activity and delay the rapid senescence of foxtail millet (Kakade et al. 2009, Maurya and Kumar 2014). Therefore, the application of a suitable concentration of $\mathrm{Zn}$ to foxtail millet could help improve its resistance to stress.

CA is the first $\mathrm{Zn}$ enzyme discovered in 1940 and is one of the most important $\mathrm{Zn}$ enzymes in photosynthetic $\mathrm{CO}_{2}$ fixation (Bird et al. 1980, Rengel 1995). CA activity and its relative gene expression are linearly positively correlated with $\mathrm{Zn}$ concentration in a certain $\mathrm{Zn}$ concentration range of plant leaf (Pandey and Sharma 2000, Pandey et al. 2002, Qiao et al. 2014). When $\mathrm{Zn}$ is deficient, CA activity decreases (Sasaki et al. 1998), but excessive Zn also decreases CA activity (Han et al. 2003). The present study shows that $40 \mathrm{mg} \mathrm{L}^{-1}$ concentration of $\mathrm{Zn}$ increased the CA activity in millet and induced the expression of the $\beta$-CA family but exerted little or no effect on the $\alpha$ and $\gamma$ families. These changes varied in the different cultivars. This result is consistent with the above findings and some papers (Wu et al. 2006, Deng et al. 2009b) also reported it. The difference in optimal growth concentrations may be due to the different species and application periods. CA is a $\mathrm{Zn}$ metalloenzyme that is activated by zinc treatment, and the activity increase may be due to the increased degree of activation after the application of $\mathrm{Zn}$. CA can increase carbon dioxide concentration at carbon dioxide fixation sites in chloroplasts, thus affecting photosynthesis. Whereas $\beta-\mathrm{CA}$ is mostly found in chloroplasts of higher plants, $\alpha-\mathrm{CA}$ and $\gamma$-CA are mostly found in cytoplasm of animals or algae, which may be the reason why zinc treatment only induces the expression of $\beta$-CA gene family. Given the limited test conditions, this experiment only analyzed the effect of spraying $\mathrm{Zn}$ fertilizer at the seedling stage of the two millet varieties. Therefore, the test results only represent the effect of $\mathrm{Zn}$ fertilizer on millet during this period. This study provided a theoretical basis for the rational application of zinc and the relationship between $\mathrm{CA}$ and photosynthesis in foxtail millet.

Conclusion: Zinc exhibits a 'low promotion and high inhibition' growth phenomenon in millet and it exhibits the best effects on growth at the concentration of $40 \mathrm{mg} \mathrm{L}^{-1}$. At $40 \mathrm{mg} \mathrm{L}^{-1}$, zinc can enhance the photosynthesis of plants, and induces the expression of the $\beta$-CA family, but the high concentration of $\mathrm{Zn}$ can damage crops and inhibit the photosynthesis of plants. The order of the effects of each concentration on millet is as follows: $\mathrm{Zn} 2>\mathrm{Zn} 1>\mathrm{Zn} 3>$ $\mathrm{CK}>\mathrm{Zn} 4>\mathrm{Zn} 5$. Studying the relationship among Zn, photosynthesis, and CA provides a theoretical support for the rational application of $\mathrm{Zn}$ fertilizer on millet.

\section{References}

Atkins C.A., Patterson B.D., Graham D.: Plant carbonic anhydrases I. Distribution of types among species. - Plant Physiol. 50: 214-217, 1972.

Bird I.F., Cornelius M.J., Keys A.J.: Effect of carbonic anhydrase on the activity of ribulose bisphosphate carboxylase. - J. Exp. Bot. 31: 365-369, 1980.

Chaney R.L.: Zinc phytotoxicity. - In: Robson A.D. (ed.): Zinc in Soils and Plants. Developments in Plant and Soil Sciences. Vol. 55. Pp. 135-150. Springer, Dordrecht 1993.

Deng Q.H., Gan L., Fu C.H. et al.: Comparison of carbonic anhydrase activities of several species in Brassica. - Plant Physiol. Commun. 45: 663-666, 2009a.

Deng Q.H., Li M.T., Yu L.J.: Cloning and expression of Brassica napus $\beta$-carbonic anhydrase cDNA. - Z. Naturforsch. 64: $875-881,2009 b$.

Fernàndez-Martínez J., Zacchini M., Fernández-Marín B. et al.: Gas-exchange, photo- and antioxidant protection, and metal accumulation in I-214 and Eridano Populus sp. clones subjected to elevated zinc concentrations. - Environ. Exp. Bot. 107: 144-153, 2014

Gao J.F.: [Plant Physiology Experiments Guidance.] - Higher Education Press, Beijing 2006. [In Chinese]

Gartler J., Robinson B., Burton K., Clucas L.: Carbonaceous soil amendments to biofortify crop plants with zinc. - Sci. Total Environ. 465: 308-313, 2013.

Graham D., Reed M.L., Patterson B.D. et al.: Chemical properties, distribution, and physiology of plant and algal carbonic anhydrases. - Ann. NY Acad. Sci. 429: 222-237, 1984.

Han J.L., Li Y.M., Ma C.Y.: [Effect of zinc on activity of carbonic anhydrase in winter wheat leaves.] - Acta Agric. Bor.-Sin. 18: 21-25, 2003. [In Chinese]

Jat R.N., Khandelwal S.K., Gupta K.N.: Effect of foliar application of urea and zinc sulphate on growth and flowering parameters in African marigold (Tagetes erecta Linn.). J. Ornam. Hort. 10: 271-273, 2007.

Kabata-Pendias A., Pendias H.: Trace Elements in Soils and Plants. Pp. 35. CRC Press, Boca Raton 2001.

Kakade D.K., Rajput S.G., Joshi K.I.: Effect of foliar application of 'Fe' and ' $\mathrm{Zn}$ ' on growth, flowering and yield of China aster (Callistephus chinensis L. Nees). - Asian J. Hortic. 4: 138140, 2009.

Kaul T., Reddy P.S., Mahanty S. et al.: Biochemical and molecular characterization of stress-induced carbonic anhydrase from a $\mathrm{C}_{4}$ plant, Pennisetum glaucum. - J. Plant Physiol. 168: 601610, 2001.

Khalifah R.G.: The carbon dioxide hydration activity of carbonic anhydrase. I. Stop-flow kinetic studies on the native human isoenzymes B and C. - J. Biol. Chem. 246: 2561-2573, 1971.

Mateos-Naranjo E., Castellanos E.M., Perez-Martin A.: Zinc tolerance and accumulation in the halophytic species Juncus acutus. - Environ. Exp. Bot. 100: 114-121, 2014.

Maurya R., Kumar A.: Effect of micronutrients on growth and corm yield of gladiolus. - Plant Arch. 14: 529-533, 2014.

Moroney J.V., Barlett S.G., Samuelsson G.: Carbonic anhydrase in plants and algae. - Plant Cell Environ. 24: 141-153, 2001.

Ohki K.: Zinc concentration in soybean as related to growth, photosynthesis, and carbonic anhydrase activity. - Crop Sci. 18: 79-82, 1978.

Okmen G., Bozanta E., Ugur A., Ceyhan N.: Zinc effect on chlorophyll $a$, total carbohydrate, total protein contents and biomass of cyanobacterial species. - J. Appl. Biol. Sci. 5: 67-73, 2011

Pandey N., Pathak G.C., Singh A.K., Sharma C.P.: Enzymic 
changes in response to zinc nutrition. - J. Plant Physiol. 159: 1151-1153, 2002.

Pandey N., Sharma C.P.: Carbonic anhydrase activity and stomatal morphology associated with zinc deficiency induced changes in faba bean. - Phytomorphology 50: 261-265, 2000.

Prasad M.N.V., Hagemeyer J.: Heavy Metal Stress in Plants: From Molecules to Ecosystems. Pp. 82. Springer, BerlinHeidelberg 1999.

Qiao X., He Y., Wang Z.M. et al.: Effect of foliar spray of zinc on chloroplast $\beta$-carbonic anhydrase expression and enzyme activity in rice (Oryza sativa L.) leaves. - Acta Physiol. Plant. 36: 263-272, 2014.

Rengel Z.: Carbonic anhydrase activity in leaves of wheat genotypes differing in Zn efficiency. - J. Plant Physiol. 147: 251-256, 1995.

Rengel Z.: Heavy metals as essential nutrients. - In: Prasad M.N.V., Hagemeyer J. (ed.): Heavy Metal Stress in Plants. Pp. 231-251. Springer, Berlin-Heidelberg 1999.

Saeed T., Hassan I., Jilani G., Abbasi N.A.: Zinc augments the growth and floral attributes of gladiolus, and alleviates oxidative stress in cut flowers. - Sci. Hortic.-Amsterdam 164: 124-129, 2013.

Sasaki H., Hirose T., Watanabe Y., Ohsugi R.: Carbonic anhydrase activity and $\mathrm{CO}_{2}$-transfer resistance in $\mathrm{Zn}$-deficient rice leaves. - Plant Physiol. 118: 929-934, 1998.

Shrotri C.K., Rathore V.S., Mohanty P.: Studies on photosynthetic electron transport, photophosphorylation and $\mathrm{CO}_{2}$ fixation in Zn-deficient leaf cells of Zea mays. - J. Plant Nutr. 3: 945-954, 1981.

Shrotri C.K., Tewari M.N., Rathore V.S.: Zn-nutrition and sucrose metabolism in Zea mays L. - Indian J. Exp. Biol. 16: 272-273, 1978.

Shrotri C.K., Tewari M.N., Rathore V.S.: Effect of zinc on chlorophyll, sugar and starch contents in maize shoots. Indian J. Exp. Biol. 17: 58-60, 1979.

Van Assche F.V., Clijsters H.: Inhibition of photosynthesis by treatment of Phaseolus vulgaris with toxic concentration of zinc: effects on electron transport and photophosphorylation. Physiol. Plantarum 66: 717-721, 1986.

Wu Y.Y., Zhang H.P., Wu D.Y. et al.: [Relations between carbonic anhydrase activities and photosynthetic rates in the leaves and pods of plants.] - Acta Bot. Bor--Occident. Sin. 26: 2094-2098, 2006. [In Chinese]

Xu K., Li Z.K., Qiu B.S., Juneau P.: Different responses to high light stress of toxic and non-toxic Microcystis aeruginosa acclimated under two light intensities and zinc concentrations. - Toxicol. Environ. Chem. 95: 1145-1156, 2013.

Zeng J., Yang L., Wang W.X.: Cadmium and zinc uptake and toxicity in two strains of Microcystis aeruginosa predicted by metal free ion activity and intracellular concentration. Aquat. Toxicol. 91: 212-220, 2009.

(C) The authors. This is an open access article distributed under the terms of the Creative Commons BY-NC-ND Licence. 